\title{
Thatched Cottage in a Fallen City
}

\section{The Poetics and Sociology of Survival under the Occupation}

\author{
Zhiyi Yang \\ Goethe University, Frankfurt, Germany \\ z.yang@em.uni-frankfurt.de
}

\begin{abstract}
This article examines the construction of lyric identities by Li Xuanti, a classicalstyle poet, cultural celebrity and prominent civil servant in collaborationist regimes based in Nanjing during the Second Sino-Japanese War. It argues that Li used his poetry to explore the confusion, ambivalence and sense of cultural pride while living with the occupiers. Despite his collaboration, a frequent identity that appears in Li's poetry is that of a yimin (loyalist), who has retreated to the inner world of reclusion. With the progress of the war, however, another identity eventually emerged in Li's poetry, namely that of a patriot. Historical allusions in Li's poems thus acquire doubleentendre, expressing his ambivalent loyalty. Li was also at the social centre of a group of like-minded collaborators and accommodators in Nanjing, bound by their common practice of classical-style poetry and arts. Their community thus becomes a special case of study for the sociology of survival under the Japanese occupation.
\end{abstract}

\section{Keywords}

Li Xuanti - collaboration - accommodation - Japanese occupation - classical-style Chinese poetry - Second Sino-Japanese War

In September 1940, Li Xuanti 李宣倜 (1888-1961), chief of the Bureau of Engraving and Printing in the collaborationist Reorganised National Government (RNG) in Nanjing, was awarded a vacant two-storey house in the Three-StepsTwo-Bridges (Sanbu liangqiao 三步兩橋) residential quarter. Built by German architects, this house had a beautiful garden, but had been damaged during the Rape of Nanjing in the winter of 1937-1938. Li repaired the damage and washed 
away whatever unseemly stains his Japanese patrons might have left behind. ${ }^{1}$ $\mathrm{Li}$, a famous classical-style poet, named the house 'West Bridge Thatched Cottage' (Qiaoxi caotang 橋西草堂), after a line by the Tang Dynasty poet Du Fu 杜甫 (712-770): 'West of Ten Thousand League Bridge, a single thatched cottage' (Wanliqiao xi yi caotang 萬里橋西一草堂). ${ }^{2} \mathrm{Du}$ Fu had followed the Tang court into exile after the capital Chang' an had fallen into the hands of rebels. Li Xuanti, however, had stayed behind in Shanghai when the Nationalist government had relocated to the hinterland and was then recruited to become a collaborator. But the irony was perhaps precisely the intention. Soon Li began to host literary salons, where, following the literati 'elegant gathering' (yaji 雅集) tradition, guests exchanged poems. His guests included not only high-, middleand low-level RNG bureaucrats capable of writing poetry, but also cultural elites loosely associated with the regime, as well as visiting Japanese sinologists. From late 1942 on, these gatherings became 'weekly salons' (xingfanhui 星飯會) held every Sunday at noon, sponsored by Wang Zhaoming 汪兆銘 (1883-1944; better known by his sobriquet Jingwei 精衛), renowned poet and leader of the RNG, and by Mei Siping 梅思平 (1896-1946), Minister of Industry and Commerce. ${ }^{3}$

As historian Timothy Brook points out, the term 'collaboration' took on its negative connotation through the rather modern idea 'that an individual could collaborate with a nation. ${ }^{4}$ The crime of wartime collaboration is existentialist, as it first of all violates the imperative of absolute loyalty to one's nation and, second, deflates the myth of united resistance. It is worth remembering, however, that 'collaboration happened when individual people in real places were forced to deal with each other'.5 Living under occupation often necessitates moral compromises and dubious allegiances. Such moral ambivalence was particularly pronounced when it came to the Wang regime, which, according to the consensus of historians outside of mainland China, lay somewhere

1 Pan Yimin 潘益民 and Pan Rui 潘蒙莱, Chen Fangke nianpu 陳方恪年譜 (Yearly Chronology of Chen Fangke) (Nanchang: Jiangxi renmin chubanshe, 2007), 46.

2 Du Fu, 'Kuangfu' 狂夫 (Crazy man), in Du shi xiang zhu 杜詩詳注, ed. Qiu Zhao' ao 仇兆鰲 (Beijing: Zhonghua shuju, 1979), 9:743. Translated in Stephen Owen, Poetry of Du Fu (Berlin: De Gruyter, 2016), 303.

3 Pan Yimin and Pan Rui, Chen Fangke nianpu, 158. On RNG Central Government personnel, see David Serfass, Le gouvernement collaborateur de Wang Jingwei: Aspects de l'État d'occupation durant la guerre sino-japonaise, 1940-1945 (PhD Dissertation, École des Hautes Études en Sciences Sociales, 2017), Annex 2.5, 804-805.

4 Timothy Brook, 'Hesitating before the judgment of history', Journal of Asian Studies 71, 1 (2012): 103-114, 104.

5 Timothy Brook, Collaboration:Japanese Agents and Local Elites in Wartime China (Cambridge, MA: Harvard University Press, 2005), 26. 
'between collaboration and resistance'. ${ }^{6}$ Werner Rings, in his study of countries occupied by Germany during World War II, points out that there were various reasons and ways for an individual to collaborate. Collaboration in Nazi-occupied Europe ranged from neutrality, in order to secure basic needs for survival, to unconditional, conditional and tactical collaboration, the last characterised by a hostile stance towards the invader. In the case of 'neutral collaboration', this means that 'life must go on'. The alleged collaborators work for the occupying force, directly or indirectly, out of their own interests, without always agreeing to the occupier's political or ideological principles; they do so to avoid bankruptcy, unemployment, hunger, chaos and ruin; they are determined to survive the war and the defeat, leading a good rather than bad life. ${ }^{7}$

In the Introduction to this special issue, we have accepted Timothy Brook's definition of 'collaborators' as 'those who were actively engaged in promoting the creation and maintenance of the occupation state. ${ }^{8}$ As Li Xuanti was a ranking member of two collaborationist regimes, he was undoubtedly a collaborator. And yet his behaviour and sentiments, as will be discussed in this paper, adhered rather to the definition of 'neutral collaboration'. He might be better described as a survivor, as he would survive not only the Japanese occupation, but also the civil war and the communist victory of 1949, relatively unscathed. He professed no particular loyalty to any ideology but to the elegant lifestyle of a traditionally educated cultural elite, detached from the politics of the day. And he was not atypical. Rather, Li represented a broad social stratum of traditional elites who, facing the slow but unstoppable advent of a modern technocratic state, felt disfranchised, as their cultural distinctions no longer guaranteed privileged access to a prominent bureaucratic career. In tenaciously guarding a lifestyle of cultural distinctions, they resisted the modern nation-

6 Liu Jie, 'Wang Jingwei and the "Nanjing Nationalist Government"', trans. Konrad Lawson, in Toward a History beyond Borders, eds Daqing Yang, Jie Liu, Hiroshi Mitani and Andrew Gordon (Cambridge, MA: Harvard University Asia Center, 2012), 205-239. See also John Hunter Boyle, China and Japan at War 1937-1945: The Politics of Collaboration (Stanford, CA: Stanford University Press, 1972); Dongyoun Hwang, Wang Jingwei, the Nanjing Government, and the Problem of Collaboration (PhD Dissertation, Duke University, 1999); David Barrett and Larry N. Shyu (eds), Chinese Collaboration with Japan, 1932-1945 (Stanford, CA: Stanford University Press, 200o); Timothy Brook, 'Collaborationist nationalism in occupied wartime China', in Nation Work: Asian Elites and National Identities, eds Timothy Brook and Andre Schmid (Ann Arbor: University of Michigan Press, 2000), 159-19o. See also the Introduction to this special issue.

7 Werner Rings, Leben mit dem Feind: Anpassung und Widerstand in Hitlers Europa, 1939-1945 (Living with the Enemy: Adaptation and Resistance in Hitler's Europe, 1939-1945) (Munich: Kindler, 1979), 112.

8 Brook, Collaboration, 13. 
state and its moral command to be patriotic, defined in twentieth-century China as loyalty to a party-state.

In these regards, the 'elegant gatherings' at the Thatched Cottage were complex literary, political and sociological events that merit careful examination. This paper represents a preliminary effort to understand what these gatherings meant for literati like Li Xuanti in their struggle to maintain the illusion of normalcy under the occupation. He and his fellow poets formed an ambivalent social space where no clear boundaries demarcated spheres of collaboration and accommodation, where patriotism was negotiable, and where traditional Chinese culture provided a rich repertoire of identities to be donned to legitimise and signify mere survival, at least to oneself.

Hailing from Houguan (Fujian Province) and often known by his sobriquets Shikan 釋载, Taishu 太疎 and Sutang 蘇堂, Li was descended from a prominent literati family of salt trade wealth. His paternal grandmother was the daughter of Shen Baozhen 沈葆楨 (1820-1879), a late Qing viceroy and reformer. His father, Li Zongyan 李宗言, passed the prefectural examination in 1882 in the same class as Lin Shu 林紓 (1852-1924), the most famous late-Qing translator of European novels. That year, Zongyan also joined a Fuzhou poetic society founded by Chen Yan 陳衍 (1856-1937), which would become a milestone in the rise of the late Qing Tongguang style of poetry. ${ }^{9}$ Li Xuanti's cousin Xuangong 李宣龔 (1876-1953, sobriquet Bake 拔可 or Mochao 墨巢) was a poet in his own right too. Despite the traditional background of his clan, Xuanti's parents decided to give him a modern education. He graduated from the Fuzhou Anglo-Chinese College and went to study in Japan, first at the military preparatory school Tokyo Shinbu Gakkō (1904-1906) — where Chiang Kai-shek 蔣介石 (1887-1975) would soon be enrolled — and then at the Imperial Japanese Army Academy (1906-1910). Despite his military training, however, Li Xuanti naturally graduated into a network of power and poetry back in China thanks to his family's literati connections.

9 See Liu Wei-Chih 劉威志, Liang Wang heping yundong xia de fushi yanzhi 梁汪和平運動 下的賦詩言志 (Peace Movement: A Discussion on the Classic Poetry of Liang-Wang et al [sic]) (PhD Dissertation, National Tsinghua University, 2017), 273-275; Yang Mengya 楊萌芽, Qingmo Minchu Songshi pai wenren qunti yanjiu 清末民初宋詩派文人群體研究 (A Study of the Song-Poetry School at the end of the Qing and the Beginning of the Republican Era) (PhD Dissertation, Fudan University, 2007), 26. 
Li had a short albeit notable career in the Qing court, serving first as Imperial Guardsman for Empress Dowager Cixi 慈禧 $\left(1835^{-1908)}\right.$ and then in the Court of Territorial Affairs (Lifanyuan 理藩院). But he did not follow the path of many prominent Tongguang poets in remaining a Qing yimin 遺民 (loyalist). Instead, he continued to serve in the newly founded republic, rising to prominence in the Beiyang regime as a secretary in the State Council and achieving the rank of lieutenant general in 1927. When the Beiyang regime was replaced by the Nationalist regime in 1928 , he did not resume his service immediately, resulting in the public perception of him as a 'Beiyang loyalist.' ${ }^{10}$ In actual fact, latest since April 1935 he had been working as a secretary in the Executive Yuan." It was possible that he was personally hired by the chairman of the Executive Yuan, Wang Jingwei, as they were acquainted on 27 October 1933 (if not earlier), at a literati 'elegant gathering' at the Tower of Sweeping Leaves (Saoye lou 掃葉樓) in Nanjing. ${ }^{2}$

After the Sino-Japanese war broke out and the capital Nanjing fell, however, Li did not follow his colleagues who were relocating to the hinterland. The reasons for not moving westwards remain unclear, though he was not alone in making this choice. He appears to have found refuge in Shanghai, where the International Settlement provided safe haven. When Liang Hongzhi 梁鴻志 (1883-1946, sobriquet Zhongyi 眾異), another poet and former Beiyang bureaucrat, was recruited by the Japanese army to establish the collaborationist Reformed Government (Weixin zhengfu 維新政府) in March 1938, he in turn recruited Li Xuanti, an old friend, to lead the Bureau of Engraving and Printing. After the RNG was founded in Nanjing on 30 March 1940, replacing the previous regional collaborationist regimes, Li managed to retain his position. He became increasingly passive, however, after the Pacific War broke out in December 1941. Soon after Wang Jingwei died in Nagoya, Japan, in November 1944, Li resigned from his offices and moved to Shanghai. When World War II ended, Li Xuanti somehow managed to escape the post-war trials of collaborators of 1946. Nonetheless, he was disgraced in public opinion and maintained a low profile. He died in Shanghai in 1961 of heart disease.

Luckily, during the last fifteen years of his life, Li was cared for by a former protégé, Mei Lanfang 梅蘭芳 (1894-1961), the male 'queen of Peking opera'.

\footnotetext{
10 Liu Wei-chih, Liang Wang heping yundong xia de fushi yanzhi, 279.

11 His name was mentioned in Shenbao 申報 (Shanghai News), 27 April 1935, 3.

12 On this gathering, see Yin Qiling 尹奇岭, Minguo Nanjing jiuti shiren yaji yu jieshe yanjiu 民國南京舊體詩人雅集與結社研究 (A Study of the Elegant Gatherings and Societies of Old-School Poets in Nanjing during the Republican Era) (Beijing: Zhongguo shehui kexue chubanshe, 2011), 188-204.
} 
They had first become acquainted in the Qing capital Beijing when Mei was a rising teen star. Li supported Mei financially, taught him poetry, composed lyrics for his new opera plays and was an avid theatre critic, promoting them in newspapers. Many of the modern Peking opera plays that made Mei a legend and a pioneer in traditional theatre reform, such as Chang'E Flying to the Moon (Chang'E benyue 嫦娥奔月) and Goddess of the Luo River (Luoshen 洛神), were co-written by Li Xuanti. His elegant lyrics, informed by the classical poetic tradition, greatly elevated the cultural register of these plays. Li's involvement in theatre also made him a mingshi 名士 (literally 'debonair scholar') in the public eye. But because of Li Xuanti's infamous collaboration during the war, his role in this earlier theatre reform is now virtually forgotten. ${ }^{13}$ Though Mei Lanfang was celebrated for his patriotic refusal to perform for Japanese troops during the war, he was never alienated from Li Xuanti. Instead, after the foundation of the People's Republic in 1949, Mei, the 'artist laureate' of New China who joined the Communist Party in 1959, continued to support Li financially and let his children study traditional poetry with Li. After Li's death, Mei paid for his funeral. A mere two months later, Mei himself passed away. ${ }^{14}$

Despite Li Xuanti's official job titles in the RNG as chief of the Bureau of Engraving and Printing and vice minister of the Army, it is unclear how much he was devoted to financial or military affairs. The RNG financial policymaker was its premier, Zhou Fohai 周佛海 (1897-1948), who also held a degree in economics from Kyoto University. When the new RNG currency zhongchuquan 中 儲券 (Central Reserve banknote) was launched in January 1941, for instance, it was seen as Zhou's crowning accomplishment, while Li appears to have had little to do with either its introduction or its success. ${ }^{15}$ RNG military forces were controlled by regional military leaders, over whom the civil leaders of the regime exerted little influence. Though Li was friendly with the Navy Minis-

13 See Huang Xiao 黃驍, 'Bie pu xinsheng pei Meilang: Mei Lanfang yu Zhuiyuxuan “muliaozhang” Li Shikan’ 別譜新聲配梅郎： 梅蘭芳與緅玉軒'幕僚長'李釋戡 (Writing another tune for Mei: Mei Lanfang and his 'chief counsellor' Li Xuanti), Zhongguo xiqu xueyuan xuebao 中國戲曲學院學報 (Bulletin of the National Academy of Chinese Theatre Arts) 39, 4 (2018): 38-42; Ma Guohua 馬國華, “Cong Li Xuanti “wolanyi caiqu” changhe kan Minguo xiqu de shanbian’ 從李宣倜握蘭箖裁曲唱和看民國戲曲的嬗變 (On the transformation of traditional theatres in Republican China from Li Xuanti's poetry creations in the Orchid Hut), Shaoguan xueyuan xuebao (shehui kexue) 韶關學院學報 (社會科學) (Bulletin of Shaoguan University: Social Sciences) 38, 10 (2017): 34-39.

14 Zuo Ren 左仁, 'Mei Lanfang ganen badiaoqian' 梅蘭芳感恩八吊錢 (Mei Lanfang repaying the debt of 'eight strings of coins'), Lantaineiwai 蘭臺內外 (Chinese Theatre On- and Backstage) 3 (2013): 11.

15 Zhou Fohai, Zhou Fohai riji quanbian 周佛海日記全編 1 (The Full Edited Diaries of Zhou Fohai, 1) (Beijing: Zhongguo wenlian chubanshe, 2003), 405-406. 
ter Ren Yuandao 任援道 (189o-1980, sobriquet Huo' an 豁溉), their friendship was mostly based on their common interest in poetry. His friendship with Ren, however, might help to explain how he escaped the post-war trials. After the outbreak of the Pacific War, Ren contacted Chongqing and began to work secretly under its directives, probably as a hedging strategy. ${ }^{16}$ When the war ended, since Chongqing could not send its troops to those territories formerly occupied by the Japanese quickly enough to prevent a communist takeover, Ren Yuandao was recruited to serve as a commander of the vanguard. It may well have been Ren who advised Li Xuanti to resign before it was too late and also protected him from being tried as a traitor. Ren himself would escape to Hong Kong after the foundation of the PRC and eventually die in Canada.

In contrast to the passive role that $\mathrm{Li}$ appears to have taken in the economic and military management of the RNG, he actively supported a few journals which featured the research and publication of classical-style Chinese poetry, including National Arts (Guoyi 國藝, 1940-1942), Accord (Tongsheng 同 聲, 1940-1945) and Sea of Learning (Xuehai 學海, 1944-1945), as an unofficial editor and frequent contributor. Since Li Xuanti's poetic anthology Selected Poems of Sutang (Sutang shishi 蘇堂詩拾, 1956) ${ }^{17}$ omitted the majority of the poems written during the occupation, these journals have become precious sources for the study of his life, poetry and thoughts during the war. These journals, in addition to the 'elegant gatherings' that he hosted, broadened the outreach of the RNG into a large group of traditionally educated cultural elites who had stayed behind in, or returned to, occupied territories. In this sense, Li Xuanti served as an unofficial RNG 'liaison officer' for cultural elites.

\section{Cultural Memory and Identity Construction}

In the official discourses of the victors, and in popular culture today, World War II is celebrated as a great saga of anti-fascism, as the battle between good and evil, and as a unique event that changed the course of world history. However, at different stages of the war, in different localities where it was fought and for different groups of people entangled in its machinery, the war was experienced in many ways and never in its totality, resulting in fragmented

16 Liu Wei-Chih, Liang Wang heping yundong xia de fushi yanzhi, 231.

17 It was published as a mimeograph in his own calligraphy. Poems written in 1956 and 1957 were later collected and published as Sutang shixu 蘇堂詩續 (Selected Poems of Sutang, Second Collection, 1957) (two fascicles). 
individual memories which do not always cohere with the grand narrative that developed after 1945. To Chinese elites, in the first stage of the war, when Japan quickly occupied large swathes of territory that included most of China's cultural, political and economic heartland, the war felt ominously familiar: they wondered if it was to become yet another war of foreign conquest like those that had led to the overthrow of mighty Chinese dynasties in the past. Were that the case, the order that would be established after an (albeit immoral) conquest would be no less legitimate than the one that it replaced. There might even have been some psychological comfort for cultural elites in thinking of the Japanese invasion in this way, since they could then fall back on familiar cultural paradigms as they sought to develop suitable patterns of response.

One such cultural paradigm, as Chiu Yi-hsuan's article in this special issue has also examined, was that of the yimin (loyalist), who remained faithful to a fallen dynasty and refused to serve a conqueror regime. Loyalists, however, did not necessarily deny the legitimacy of the new regime: they could not serve it, owing to the obligatory fealty that they felt towards their erstwhile patrons. Responses conforming to this paradigm had already appeared when the Qing Dynasty was replaced by Republican China and when the Beiyang government was replaced by the Nationalist government. Living under the Japanese occupation, therefore, some might perceive the ethical challenge inherent in responding to an invading foreign force as not unlike that faced by pre-modern loyalists: the Mongol Yuan and the Manchu Qing were once 'foreign' conquerors too, but the ethnicity of the ruling houses did not prevent their dynasties from eventually being accepted as 'Chinese'.

There were, however, crucial differences. First of all, the Chinese Nationalist government of Chiang Kai-shek was yet to surrender, and was continuing to lead the resistance from Chongqing. Second, perhaps owing to the rise of nationalism as the default paradigm of political legitimisation, Japan did not integrate occupied mainland Chinese territories into its own colonial empire (as it had done with Taiwan and Korea in the late nineteenth and early twentieth centuries). Instead, it established collaborationist regimes under nominal Chinese control. These client regimes, moreover, all chose familiar symbols of legitimacy: Manchukuo styled itself as the recovery of the Qing Dynasty on its native Manchu soil; the Provisional Government in north China and the Reformed Government in Nanjing were led respectively by former Beiyang bureaucrats, with both adopting Beiyang symbols, including the five-coloured national flag (wuse qi 五色旗); and the RNG claimed itself to be the same Nationalist government that had been nominally established by Sun Yat-sen, 'returning to the capital' (huandu 還都) of Nanjing. It continued to adopt the 
'blue sky, white sun, and a wholly red earth' (qingtian bairi man di hong 青天 白日滿地紅) national flag, the кMT party flag and the Sun Yat-sen personality cult, among other trappings of legitimacy. All these were designed to encourage the perception that the client regimes were fully Chinese, notwithstanding Japanese bayonets, and to bolster the wishful thinking that full Chinese control might be reasserted one day.

Li Xuanti's lyrical construction of his political identity, consequently, can also be divided into three phases. From the establishment of the Reformed Government until the autumn of 1940, his poems lack historical allusions that might suggest an identification with historical figures. Instead, they betray a sense of confusion and shame. From late 1940 until early 1942, just after the outbreak of the Pacific War, he frequently refers to historical precedence in his poetry to style himself as a loyalist, a recluse or an exile, external to the politics of the day. And from 1942 through until the end of the war, with the failure of the Japanese militarist venture becoming increasingly clear, he begins to style himself after patriots living in periods of division, primarily the Southern Song poet Lu You 陸遊 $\left(1125^{-1210}\right)$, yearning for national unity. Such lyrical performance of his identity, furthermore, was exemplary of the socio-literary circles in which Li found himself.

In the following section, many of Li Xuanti's literary associates will be introduced. Since they were cultural figures who so far have received virtually no attention from historians, I will give their dates, names, sobriquets (used when they published in literary journals) and, whenever necessary, brief descriptions, to illustrate the social composition of this circle of literati collaborators and accommodators.

In the first phase, Li's poetic social circle consisted primarily of former Beiyang colleagues, including Gao Jinchen 高近宸 (?-?, sobriquet Zihuo 子 矱 or Gusou 固鼠), Ren Yuandao, Chen Daoliang 陳道量 (1898-1970, sobriquet Liaoshi 廖士), Chen Zhaoting 陳趙亭 (1899-1962, sobriquet Shirong 世 鎔 or Boye 伯冶), and Huang Maoqian 黃禁謙 (?-1950, sobriquet Moyuan 默 園 or Moyuan 嘿園). Some of these individuals had never fully embraced the legitimacy of the Nationalist government that had been established in Nanjing in 1928 and were resentful of the latter's 'mismanagement' of China and its failure to defend China against foreign invasion. They thus perceived collaboration as an opportunity for a political 'comeback' through which they could realise their political ambitions. Such sentiments were most clearly revealed in a poem by Liang Hongzhi written immediately after his return to Nanjing in February 1938. It boldly declares that 'I carry on one shoulder the thousand buckets of this world's sufferings' (shinan qian jun wo yijian 世難千鈞我一肩). In this poem, Liang compares himself to Zhuge Liang 諸葛亮 (181-234) and 
Guan Zhong 管仲 (725-645 BCE), two famous literati chancellors who served in times of chaos. ${ }^{18}$ In contrast, perhaps partially owing to Li Xuanti's record of service in the Nationalist regime, Li could hardly declare a lack of responsibility for China's loss. In poems written while touring Nanjing in the spring after the Nanjing Massacre, he juxtaposes the beautiful images of an innocent nature in recovery ${ }^{19}$ with his own sentiments of sorrow, shame, nostalgia and confusion. A heptasyllabic poem on hearing that the crab apple in a garden has failed to blossom runs:

名園景物未全荒 憔悴今聞到海棠

淡月籠紅思夜好 I think of the fine nights when pale moonlight encased the red;

暖風催綠怨春忙 And lament the busy springs when warm winds hastened greening.

花時賓客詩猶綺 When the season comes, poems of visitors remain flowery; 劫後王孫盡作糧 After the catastrophe, princes and lords have become fertilisers.

自有聯床佳興在 Reclining on connected couches, we rejoice in poetry, 任渠蛙黽滿池塘 Despite the clamour of frogs swarming in a pond..$^{20}$

Though multiple poems of Li Xuanti's written in 1938 hint at the Nanjing Massacre, none explicitly excoriate the Japanese invaders for being responsible. This poem is no exception. The first line implicitly points to the invasion and its consequences. The second couplet, however, is nostalgic, expressing the poet's longing for the innocent pleasures of the past. The third couplet is startling: the visitors to the garden are most likely collaborators returning to the fallen city, whose flowery poetry is in wanton ignorance of the carcasses rotting to

18 Liang Hongzhi, ‘Eryue ershiqiri ti Jinling xingguan’二月二十七日題金陵行館 (On the villa in Nanjing on 27 February), in Yuanjuge shizhu 爰居閣詩註 (The Commentated Edition of Poetry in the Pavilion of Temporal Lodge), Chen Shirong 陳世鎔 commentator (self-published, 1945 [?], Shanghai Municipal Library Collection), 11:2.

19 As Jeremy Taylor points out, 'spring in recovery' was a common trope in RNG political propaganda in 1940 to legitimise their regime as the rebirth or the regeneration of the nation. This point is raised in Jeremy E. Taylor, Iconographies of Occupation: Visual Cultures in Wang Jingwei’s China, 1939-1945 (Honolulu: University of Hawai'i Press, forthcoming).

20 Li Xuanti, Sutang shishi 蘇堂詩拾 (Selected Poems of Sutang) (self-published, 1956; Nanjing Municipal Library Collection), 26b. 
feed the very flowers that they are enjoying watching. Li Xuanti is well aware that he himself is among these collaborators: while he is enjoying the domestic pleasure of poetry and friendship, the world outside is filled with the clamour of 'swarming frogs' - a metaphor of moral depravity. In a poem written on 24 September, he declares:

那有是非供譽毀 I have done no right or wrong to be praised or condemned; 未知死所做生涯 Knowing not where to die, I keep living. ${ }^{21}$

In another poem on visiting the Linggu Temple 靈谷寺, he writes:

遮門敗葉無人掃 Rotting leaves piling against the gate have no one to clear them;

移榻殘僧訝我回 A disfigured monk moving couches is surprised to see me back. $^{22}$

Linggu Temple was where the Nationalist government had enshrined soldiers who had fallen in the Northern Expedition (1926-1927) that vanquished the Beiyang regime and united China. The temple was damaged during the siege of 1937, as it lay in the path of the Japanese army's advance from Shanghai to Nanjing. For Li Xuanti, a civil servant in the Beiyang, Nationalist and now collaborationist regimes, it must have been particularly sorrowful to visit this place, as he wrote three poems on this single visit. ${ }^{23}$ It is unclear why the disfigured monk was doing something so mundane as rearranging meditation couches-perhaps because not many of his colleagues had survived. In any case, his 'surprise' to see Li back in town must have been deeply embarrassing for the latter (interestingly, in the 1956 anthology, 'surprised' was changed to 'delighted' $[x i$ 喜] $) .{ }^{24}$ But, as a man of letters, what could he have done to make a difference? In a poem entitled 'Expressing my outrage' written in the autumn of 1937, he laments the loss of Chinese territories and ends with:

\footnotetext{
21 Li Xuanti, 'Jiuyue ershisiri yezuo' 九月二十四日夜作 (Written in the evening of 24 September), Guoyi 國藝 (National Arts) 1, 1 (1940): 38.

22 Li Xuanti, 'Shiyue erri Linggu si shi tongyou'十月二日靈谷寺示同遊 (Visiting the Linggu Temple on 2 October; written to show my fellow visitors), Guoyi 1, 1 (1940): 38 .

23 See Li Xuanti, 'Yiyou weijin zaifu' 意有未盡再賦 (Feeling incomplete, I write a second poem) and 'Linggusi tibi' 靈谷寺題壁 (Written on the wall of the Linggu Temple), Guoyi 1, 1 (1940): 38 .

24 Li Xuanti also retitled the poem 'Qiusi' 秋寺 (Temple in autumn), in Sutang shishi, 31 b.
} 
腐儒扼腕終無補 A rotten scholar wringing his wrists in despair helps nothing!

時日何因及汝亡 Oh, the sun, when can I ever die with you? ${ }^{25}$

The last line alludes to a sentence in the Book of Documents: 'When would the sun ever die? I swear to die with you!' (shi ri he sang yu ji ru xie wang 時日曷 喪予及汝偕亡) ('Oath of Tang' or Tang shi 湯誓). If we read the 'sun' ( $r i$ 日) as a reference to Japan (Nihon 日本), the 'Empire of the Sun', this couplet may be Li's strongest expression of his anti-Japanese sentiments. Such explicit expressions of patriotism, however, disappear from his poems after he started to work for the collaborationist regimes. In a poem written in the autumn of 1938 , he simply declares:

邦國已非衰朽事 Matters of the state are no longer the business of the senile; 卻從兒女漫思量 I leave it to the thoughts and plans of my children. ${ }^{26}$

After the foundation of the RNG, Li Xuanti was reintegrated into the poetic circle around Wang Jingwei. That autumn he responded to three poems by Wang Jingwei, in which he praises Wang as being driven by a passionate concern for the land and by his humaneness to pick up the broken pieces of conquered territories, ${ }^{27}$ as a pillar holding up the falling sky ${ }^{28}$ and as a mythological bird trying to fill a surging ocean with pebbles carried in its bleeding beak. ${ }^{29}$ The last comparison refers to Wang's sobriquet Jingwei. In an ancient myth recorded in the Classic of Mountains and Seas, ${ }^{30}$ the jingwei bird is the reincarnation of a young princess drowned in the East Sea. In wrathful vengeance, the bird tirelessly carries pebbles in its bleeding beak to fill up a surging ocean. Adopted by Wang in 1905 when he joined the anti-Qing revolutionary movement, this name

25 Li Xuanti, 'Shufen' 書憤 (Expressing my rage), in Sutang shishi, 27b.

26 Li Xuanti, 'Bumei' 不寐 (Sleepless), Guoyi 1, 2 (1940): 50.

27 Li Xuanti, 'Manjiang hong: He Shuangzhaolou yun' 滿江紅·和隻照樓均 (韻) (Matching the rhyme of 'Double-shining tower' [a.k.a. Wang Jingwei], to 'A river full of red'), Guoyi 2, 2 (1940): 6.

28 Li Xuanti, 'Yu meiren: He Shuangzhaolou' 虞美人·和雙照樓 (Matching the rhyme of 'Double-shining tower' to 'Yu the beauty'), Guoyi 2, 2 (1940): 34.

29 Li Xuanti, 'Qianti [Gengchen zhongqiu]: He Shuangzhaolou yun' 前題 [庚辰中秋]·和雙 照樓韻 (Matching the rhyme of 'Double-Shining Tower', the same title [Mid-Autumn Day, 1940]), Guoyi 2, 3 (1940): 47 .

30 Yuan Ke 袁珂, Shanhaijing jiaozhu 山海經校注 (A Commentated Edition of the Classic of Mountains and Seas) (Shanghai: Shanghai guji chubanshe, 1980), 92. The classic was compiled in the first century вСE, though the myths are believed to be much older. 
expressed Wang's wish to be a revolutionary martyr. Notably, Li Xuanti had never praised Liang Hongzhi, leader of the Reformed Government, in such lofty terms. This was either because of Li's genuine admiration for Wang or because he felt a particular urgency to prove his loyalty to the new regime. His social circle was now enriched by poets who came to Nanjing with the Wang clique, primarily Liao Entao 廖恩壽 (1864-1954, sobriquet Chan' an 懺鶬), Chen Zhu 陳 柱 (189o-1944, sobriquet Zhuzun 柱尊), Zhao Zunyue 趙尊岳 (1898-1965, sobriquet Shuyong 叔雍), Long Yusheng 龍榆生 (1902-1966, sobriquet Muxun 沐勛), and later Qian Esun 錢喜孫 (1908-2003, sobriquet Zhonglian 仲聯) and Mao Jingfan 冒景璠 (1909-1988, sobriquet Xiaolu 效魯, Xiaolu 孝魯 or Shuzi 叔子). Japanese poets Imazeki Tenpō 今関天彭 (1882-1970) and Hashikawa Tokio 橋 川時雄 (1894-1982) were also frequent guests. When Li Xuanti moved into the Thatched Cottage, Chen Zhaoting became his next-door neighbour. Amicable, generous, well-connected and widely liked, Li was the centre of this social circle. He was almost never alone.

But the company of such talented poet friends did little to alter Li's increasing despair. This was perhaps because it had become obvious that the Japanese puppet masters had little intention to grant the RNG any actual autonomy or to realise 'peace' in China without total conquest. Regardless of altruistic ideals that may have originally motivated Wang Jingwei to collaborate (and may have motivated his followers to continue to believe in the virtues of collaboration), the RNG's true status as a client regime, whose very existence was reliant on the support of a belligerent occupant hostile to its professed nationalist agenda, would never change.

Long Yusheng, who came to Nanjing as a legislator, redirected his energy to literature and founded Accord in October 1940. In its first issue, Li Xuanti published six poems entitled 'Poetry in the West Bridge Thatched Cottage', formally introducing his new studio's name to the literary public. In these poems, he compares himself to Ruan Ji 阮籍 (210-263) and Tao Qian 陶潛 (352?-427? or Yuanming 淵明), heroes of the 'reclusion' tradition. ${ }^{31}$ As he writes in a poem addressing Chen Zhaoting: ${ }^{32}$

31 See Li Xuanti, 'Qiaoxi caotang shi liushou' 橋西草堂詩六首 (Six poems in the West Bridge Thatched Cottage), Tongsheng 同聲 (Accord) 1, 1 (1940): 106-108. On the Chinese reclusion tradition, see, for example, Alan Berkowitz, Patterns of Disengagement: The Practice and Portrayal of Reclusion in Early Medieval China (Stanford, CA: Stanford University Press, 200o).

32 Li Xuanti, 'Xizeng Chen Boye' 戲贈陳伯冶 (A witty poem to Chen Boye), Tongsheng 1, 1 (1940): 106-107. 
地偏車馬稀 This remote location is rarely visited by chariots or horses;

勤過獨之子 Who frequents my hut? You and you only.

The first line of the couplet refers to Tao Qian's celebrated fifth poem in the 'Drinking Wine' (Yinjiu 飲酒) series, which states:

結盧在人境 I built my hut in a place where people live,

而無車馬喧 And yet there's no clatter of carriage or horse.

問君何能爾 You ask me how that could be?

心遠地自偏 With a mind remote, the region too grows distant. ${ }^{33}$

Tao's poem describes a farmer-recluse who has not abandoned human society. The 'distantness' of his hut is the result of the 'remoteness' of his mind. Similarly, Li Xuanti's 'Thatched Cottage' was in reality a villa close to the city centre of Nanjing. Yet, as his poem hints, his mind was already 'remote' from the centre of power. This sentiment is also revealed in another poem in this series describing the environment of his studio: ${ }^{34}$

散策騎驢從所欲 Following a cane, riding a donkey, I go wherever my heart desires;

未須一舸逐鴟夷 No need to chase Chiyi, away on a dinghy.

'Riding a donkey' refers to Ruan Ji, who was related to the Cao royal family of the Wei Dynasty. After the Sima family usurped the throne and founded the Jin Dynasty, Ruan Ji continued to serve in the court, but disengaged from its actual administration. Once the emperor asked Ruan Ji what he wanted, and he declared that he was fond of the city of Dongping and would like to be its mayor. His wish was granted. Ruan then rode a donkey (a commoner's means of transport) to Dongping and resigned there ten days later, claiming that he was satisfied. ${ }^{35}$ The second line refers to the story of Fan Li 范蛍 $(536-448$ в CE), who helped the King of Yue to recover the land lost to the kingdom of Wu and

33 For the Chinese original, see Tao Qian, Tao Yuanming ji 陶淵明集 (The Poetry of Tao Yuanming), Lu Qinli 逯欽立 commentator (Beijing: Zhonghua shuju, 1979), 89. For the English translation, see Burton Watson, The Columbia Book of Chinese Poetry (New York: Columbia University Press, 1984), 135.

34 Li Xuanti, 'Qiaoxi jimu' 橋西即目 (Random sights to the west of the bridge), Tongsheng 1 , 1 (1940): 107.

35 Zhang Yin 張隱, Wenshi zhuan 文士傳 (Biographies of Literati), cited in Ouyang Xun 歐 陽詢, Yiwen leiju 藝文類聚 (Classified Extracts from Literature) (Shanghai: Shanghai guji chubanshe, 1982), 94:1629. 
then retired. He sailed on to the Five Lakes on a dinghy, assumed an alias and became a rich merchant. ${ }^{36}$ His alias, Chiyi Zipi 鴟夷子皮, or 'the leather bag' (used for floating), commemorated his friend Wu Zixu 伍子胥 (d. 484 BCE), a minister of Wu who advised his king not to be deceived by the King of Yue but was ignored and killed, his skin made into a leather bag. Apparently, by choosing Ruan Ji's over Fan Li's example, Li Xuanti is stating that he would rather be a 'court recluse' (chao yin 朝隱), who remains in office but has internally disengaged from politics, than withdraw from politics altogether to protect himself and to protest. He hints at the reason in the sixth poem, entitled 'Studio life':37

\section{短世輕輕換幾秦 In a brief time a few Qins have promptly rotated;}

何知中壽已遺民 An unexpected remnant loyalist in my midlife.

'Qin Dynasty' is a synonym for all autocratic political regimes that have united, or tried to unite, the whole of China. For Li, the 'Qin Dynasties' referred to here are likely to include the Qing Dynasty, the Beiyang regime, the Nationalist regime and imperial Japan - but not the collaborationist regimes, as these lacked the authority to declare themselves 'Qin'. Li Xuanti thus jokes about himself being a 'loyalist' - with apparent sarcasm, since he had served in all of these regimes. However, this might also be a camouflaged apology, declaring his service to be a kind of 'reclusion in the court', his mind disengaged from the politics of the day.

It should be noted that this was the first time since joining the Reformed Government in February 1938 that Li had tapped into China's reservoir of cultural memory to construct a kind of cultural and political identity. As Jan Assmann's work on cultural memory points out, identity is sociogenic. 'Individual consciousness is sociogenic not only through socialization (from outside in) but also because it creates community by being the bearer of a collective self-image, or awareness of the "we". 38 Cultural memory is the collective framework of reference by which a community defines itself. In classical-style Chinese poetry, memory of the past is manifested not only through allusions (diangu 典故), but also through the choice of style, voice and motif, all having the potential of subtly nodding to a shared reservoir of cultural memory

36 Sima Qian 司馬遷, Shiji 史記 (Records of the Grand Historian) (Beijing: Zhonghua shuju, 1959), 41:1740-1753.

37 Li Xuanti, 'Zhaiju' 齋居 (Studio life), Tongsheng 1, 1 (1940): 108.

38 Jan Assmann, Cultural Memory and Early Civilization: Writing, Remembrance, and Political Imagination (Cambridge: Cambridge University Press, 2011), 112. 
that only an insider can detect. This cultural memory can be further divided into the 'the archive and the store house' and the 'working memory'; the latter is actualised in a society's or in an individual's recollection. ${ }^{39}$ Li's reference to cultural paradigms suggests his active recollection of his identity, the result of his gradual emergence out of confusion and his achievement of certain clarity in understanding his choice. The paradigm into which he attempted to fit himself is that of a 'court recluse' cum 'loyalist', philosophically 'disengaged' from the current power structure. In poems that he published in National Arts and in Accord over the following year and a half, he repeatedly elaborates upon this identity and justifies his self-comparison. In a poem matching Gao Jinchen's in rhyme, for instance, he declares: ${ }^{40}$

早身禪悅心常住 Long indulged in the Chan pleasure, my heart is constantly still,

肯為功名骨盡枯 Unwilling to turn into withered bones for worldly feats.

大浸稽天塵劫耳 A flood brimming to the sky is the kalpa of this dusty world; 與君藕孔忍須舆 You, sir, and I shall hide in a lotus root's hole for a while.

Chan (Zen) is a Buddhist term literally meaning meditation. Kalpa, also a Buddhist term, refers to the catastrophe at the end of a cyclical world; after cosmic destruction, a new world will be born. Using this term to refer to the Second Sino-Japanese War, Li Xuanti signals his optimism that, after the horror of war, a new chapter of Chinese history may soon begin. He and his friends, the literati survivors, will hide from the destruction in a 'lotus root's hole' - a metaphor for his Thatched Cottage, sheltered by the Wang regime (the lotus root' itself) in a fallen city in the invaders' grip (the 'flood').

Another identity that $\mathrm{Li}$ often finds for himself is that of an exile, primarily in the disguise of the Song poet Su Shi 蘇軾 (1037-1101, style name Dongpo 東坡), who was banished to Huizhou (Guangdong Province) and Danzhou (Hainan Island), the margins of Chinese civilisation in the eleventh century. Li had long admired Su Shi. In this second phase, however, Li specifically compares himself to Su Shi in exile. This comparison started around the beginning of 1941. In a poem written on 11 February that year (after the Chinese New Year), Li com-

39 Aleida Assmann, 'Canon and archive', in Cultural Memory Studies: An International and Interdisciplinary Handbook, eds Astrid Erll and Ansgar Nünning (Berlin: De Gruyter, 20o8), 100.

40 Li Xuanti, 'Ciyun Zihuo' 次均子矱 (Matching the rhyme of Zihuo's poem), Tongsheng 1, 2 (1941): 110 . 
pares his residence to Tao Qian's 'Peach Blossom Spring' (Taohuayuan 桃花源) and himself to Su Shi in Huizhou: ${ }^{41}$

繽紛落岸梅 Plum petals cascade over the riverbank, 仿佛桃源境 Like a scene in the Peach Blossom Spring. 道人午睡足 The Man of the Way has had a nice afternoon nap; 聊此事幽屏 He engages his mind in the remote and the secluded.

This poem plays upon associations with Tao's said poem and Su Shi's emulation of Tao Qian during his periods of exile. The Peach Blossom Spring, through Su Shi's rewriting, becomes an 'inner utopia' that shields the poet from external circumstances and creates a space of freedom. ${ }^{42}$ The 'afternoon nap' line reminds the reader of Su Shi's poem 'Letting go my brush': ${ }^{43}$

報道先生春睡美 Reported: the Master is sound in a spring sleep; 道人輕打五更鐘 Daoist, strike lightly the five o'clock bell.

Li Xuanti's admiration of Su Shi was expressed in his very sobriquet Sutang 蘇 堂, or the 'Su Hall'. Though the term daoren 道人 refers to different personae in their poems (the Daoist in Su's case), it literally means 'the Man of the Way' and is used by Su elsewhere to refer to himself too. Su Shi's poem was defiant since, as an exile, he was supposed to repent for his mistakes, not celebrate a life of ease. Legend has it that he was banished to Hainan because of this poem. ${ }^{44} \mathrm{Li}$ Xuanti expressed similar defiance in a poem reporting a rumour that he had been sick and died:45

坊裏維摩病未成 Vimalakirti in the city does not manage to get ill; 東坡海外漫相驚 And don't be surprised that Dongpo has survived Hainan.

41 Li Xuanti, 'Zhengyue shiliuri yuhou jian Yuanxi huiyin zhugong' 正月十六日雨後簡元 夕會飲諸公 (After the rain of the sixteen day of the first month, written to invite my friends for a drink), Tongsheng 1, 4 (1941): 101.

42 See Zhiyi Yang, 'Return to an inner utopia: Su Shi's transformation of Tao Qian in his exile poetry', T'oung Pao 99 (2013): 329-378.

43 Su Shi, 'Zongbi' 縱筆 (Letting go my brush), in Su Shi shiji 蘇軾詩集 (The Complete Poetry of Su Shi), ed. Kong Fanli 孔凡禮 (Beijing: Zhonghua shuju, 1982), 40:2203.

44 Zeng Jili 曾季暒, Tingzhai shihua 艇齋詩話 (Poetry Talks in the Skiff Studio) (Hong Kong: Guangwen shuju, 1971), 66-67.

45 Li Xuanti, 'Haishang you chuan yu bing qie si zhe’ 海上有傳余病且死者 (On a rumour in Shanghai that I am sick or perhaps even dead), Tongsheng 1, 6 (1941): 131. 
餘生銷盡飛騰意 For the rest of my life, I have burnt all desires to be important;

扶杖還思見太平 Leaning on a cane, I still dream of living to see a world in peace.

In the Vimalakirti Sutra, one of the central canons of Chan Buddhism, the layman Vimalakirti famously pretends to be ill to test his visitors' wisdom. But perhaps Li Xuanti is also comparing himself to Wang Wei 王維 (699-761), the Tang Dynasty poet who adopted Vimalakirti as his style name: after the capital Chang' an fell, Wang Wei did not follow the Tang court into exile (as Du Fu did) but stayed in Chang' an and was forced to collaborate with the rebels' regime. After the dynasty recovered the capital, Wang remained in office but became a 'court recluse'. Su Shi, against all odds, survived Hainan to come back to the mainland. In this poem, Li again asserts himself to be a recluse and exile, marginalised in the bureaucratic system. The sense of shame in his early poems written under the Reformed Government is now replaced by defiance, which might suggest that Li eventually learned to reconcile himself to his collaboration, adopting even a gesture of moral confidence typical of Wang Jingwei and many of Wang's followers.

One young friend who perfectly understood Li Xuanti was Qian Zhonglian. In his preface to a set of poems on a painting entitled 'The West Bridge Thatched Cottage', he not only explicitly compares Li Xuanti to Wang Wei in the 'court recluse' phase of life, but concludes: 'Where is the Peach Blossom Spring? One hides in the ocean of humanity. A big disaster lies in the future; but here one finds pleasure. Thus I feel fortunate on the Master's behalf.'46 $\mathrm{Li}$ Xuanti's 'Thatched Cottage' was a refuge from the real troubles of the world.

The third phase of Li's identity transformation began in the spring of 1942, after the outbreak of the Pacific War. As Liu Wei-chih has analysed, in a poetic exchange with Wang Jingwei and Long Yusheng concerning a painting acquired by Ren Yuandao on the motif of Jing Ke's 荆軻 assassination of the King of Qin, Li Xuanti's two poems may be read as a 'subtle remonstration' suggesting that Wang play the assassin: pretending to surrender to Japan, only to strike with a proverbial 'dagger' at the final moment. ${ }^{47}$ From that late spring onwards, and

46 Qian Zhonglian, 'Qiaoxi caotang tuyong xu' 橋西草堂圖詠序 (Preface to the collected poems on the painting of West Bridge Thatched Cottage), Tongsheng 3, 3 (1943): 10.

47 See Liu Wei-chih, Liang Wang heping yundong xia de fushi yanzhi, 235-237. I myself have also analysed this exchange in Zhiyi Yang, 'The memory of an assassin and problem of legitimacy in the Wang Jingwei regime (1940-1945)', Harvard Journal of Asiatic Studies (forthcoming). 
with the failure of Japan's venture in the Pacific increasingly clear, he began to compare himself in his poems to patriots like Xin Qiji 辛棄疾 (1140-1207) and $\mathrm{Lu}$ You, both Southern Song poets yearning for China's reunification.

On 14 November 1943, a stellar cast of poets, including Long Yusheng, Xia Jingguan 夏敬觀 (1875-1953), Li Peiqiu 李霜湫 (1884-?), Huang Maoqian 黄 禁謙 (?-1950), Yang Wuyang 楊無恙 (1894-1952), Chen Zhaoting and Qian Zhonglian, ${ }^{48}$ gathered at Li Xuanti's home to celebrate the 819th anniversary of Lu You's birth. Since the Qing Dynasty, it had been common for poets to celebrate Su Shi's posthumous birthdays. Li also hosted 'elegant gatherings' on Su's birthdays in 1942 and $1943 .{ }^{49} \mathrm{He}$ had never, however, joined celebrations for Lu You's birthday before. In 1941, when a few poets in Li's social circle exchanged poems on Lu's birthday, no contribution from Li is found..$^{50}$ Thus it appears significant that Li initiated the celebration in 1943, five months after the Battle of Midway. On this occasion, Li Xuanti's poem states: ${ }^{51}$

小儒橫涕望京華 A petty scholar, tears streaming down his cheeks, gazes at the capital,

無計車書更一家 Seeing no way for chariots and writing to be unified.

北定中原心豈死 Pacify the Central Plains in the north!一-this heart is yet to die;

西收太華願猶奢 Take back Mt Hua in the west!—this wish is still extravagant.

詩餘萬首牛毛細 What remain are ten thousand poems, fine like cow hairs; 酒湧千悲馬齒加 Intoxicated, a thousand kinds of sorrow surge, in an aging horse.

48 For a translation and detailed analysis of Qian's poem, see Zhiyi Yang, 'Site: the impossibility of remembering the past at Nanjing', Modern Chinese Literature and Culture 32, 1 (2020): 259-262.

49 See Li Xuanti, 'Dongpo shengri shangke caotang Yizhangshi xiancheng ciyun' 東坡生日 觞客草堂異丈詩先成次韻 (On Dongpo's birthday I invite guests to the Thatched Cottage for a drink; Zhongyi first completed his poem; I thus match its rhyme), Tongsheng 2, 3 (1942): 112; Li Xuanti, 'Dongpo shengri yinke caotang de yezi’ 東坡生日飲客草堂得也字 (On Dongpo's birthday I invite guests to the Thatched Cottage for a drink; drawing the lot of 'ye' as the rhyme of my poem), Yayan 雅言 (Elegantiae) 5, 6 (1943): 1.

50 Xia Jingguan, 'Shuidiao getou: Fangweng shengri zuo' 水調歌頭·放翁生日作 (On Fangweng's [a.k.a. Lu You] birthday, to 'A water tune'), Tongsheng 1, 4 (1941): 108; Lin Baoheng 林葆恆, 'Hangongchun: Fangweng shengri' 漢宮春·放翁生日 (Fangweng's birthday, to 'Spring in the palace of Han'), Tongsheng 1, 5 (1941): 148-149; Ren Yuandao, 'Mulan huaman' 木蘭花慢 (To 'Magnolia flowers, a slow tune'), Guoyi 3, 1 (1941): 33.

51 Li Xuanti, 'Shiyue shiqiri ji Qiaoxi caotang zuo Fangweng shengri'十月十七日集橋西草 堂作放翁生日 (Gathering in the West Bridge Thatched Cottage to celebrate Fangweng's birthday on 17 October), Tongsheng 3, 8 (1943): 49 . 
斜日龜堂資想像 When the sun sets, I imagine you sitting in the Tortoise Hall; 城頭終古有荒笳 A desolate reed pipe blows on the city: sound of time immemorial.

After the Qin unification of China in $221 \mathrm{BCE}$, measures of chariots and styles of writing were standardised so that people could travel around the empire and communicate with each other. Li Xuanti's first couplet expresses a wish for unification. He does not explicitly say, however, who should unify whom. In the guise of Lu You, he could well be wishing for the RNG to unify China. This is also what is literally implied in the second couplet, as the RNG controlled only the southeast: its 'sovereignty' over north China was only nominal, as the northeast was under Manchukuo jurisdiction while the area around Xi' an (Mt Hua) was a communist stronghold. National reunification under the RNG, in regard to the situation at the end of 1943, was indeed an extravagant wish. However, the first line also calls to mind Lu You's famous couplet: ${ }^{2}$

遺民淚盡胡塵裏 The loyalist's tears fall into the barbarian dust;

南望王師又一年Ａnother year of gazing south, waiting for our king's army!

Lu You in his poem assumes the eyes of a Song loyalist living under the northern Jin Dynasty (Jin was founded by the ethnic Jurchens, hence 'barbarian'), waiting for the recovery by his rightful king. If $\mathrm{Li}$ in his poem compares himself not to Lu You but instead to the 'loyalist' in Lu You's poem, then his poem could be read as an expression of loyalty to Chongqing instead. The ambivalence of poetic speech enabled double-entendre, allowing Li Xuanti to create questions in the minds of the readers who knew him as a 'collaborator' while also giving him plausible denial if he was ever challenged by his Japanese patrons.

In his pioneering 1993 book on intellectual choices in occupied Shanghai, Poshek Fu proposes to study 'the problem of human responses to occupation.' ${ }^{53}$ As he argues, 'wartime Shanghai exhibited a complexity and ambiguity

52 Lu You, 'Qiuye jiangxiao chu limen yingliang yougan' 秋夜將曉出篗門迎涼有感 (At daybreak of an autumn night I went out of the gate and inspired by a chilly breeze), no. 2, in Jiannan shigao jiaozhu 劍南詩稿校註 (A Commentated Edition of the Poetry of Jiannan [a.k.a. Lu You]), ed. Qian Zhonglian (Shanghai: Shanghai guji chubanshe, 1985), 25:1774. Poshek Fu, Passivity, Resistance, and Collaboration: Intellectual Choices in Occupied Shanghai, 1937-1945 (Stanford, CA: Stanford University Press, 1993), xi. 
of moral choices that defies such simplistic stereotyping' as the Manichean view of good versus evil. His book thus proposes a 'tripartite model of intellectual responses to the "grey zone" of the Japanese Occupation', namely, resistance, passivity and collaboration. ${ }^{54}$ The collaborators he studied were a group of contributors to the journal Reminiscence (Gujin 古今), which 'provided many intellectual collaborators ... with space for atonement, becoming the vehicle of a self-pitying, self-justifying, and reclusive literature that befitted yimin'.55 Through writing nostalgic lyrical essays, these classically educated collaborators found a 'personal space' in which to distance themselves from the politics of the day.

For the most part, Fu's observation of the collaborators' sentiments of guilt, nostalgia and escapism also applies to the Nanjing group, though their chosen means of communication was classical-style poetry and they in general possessed greater cultural and social capital than the obscure contributors to Reminiscence that Fu examined. However, unlike a journal, Li Xuanti's Thatched Cottage was a concrete social space for their physical gathering. The Nanjing group was thus also bound by family ties, native place links, overlapping career paths, common hobbies and accidental encounters-not unlike any social group of artists or writers inhabiting a modern metropolis.

Li's was a relatively egalitarian space. Though Wang Jingwei, the head of the RNG, does not seem to have joined any of Li's gatherings, senior leaders, including Liang Hongzhi and Ren Yuandao, were occasionally found here. Most regulars, however, were high- to mid-level bureaucrats who had known Li before the RNG period. Gao Jinchen, Chen Zhaoting and Huang Maoqian all hailed from Fujian; they most likely had known Li Xuanti as a colleague in the Qing court or in the Beiyang government. Chen Daoliang had worked with Li in the Executive Yuan under Wang Jingwei and, earlier, in the Reformed Government under Liang Hongzhi. Mao Jingfan, like Li, descended from a prominent literati family and was appreciated by senior Tongguang poets. When they gathered in this social space, however, poetic skill became the predominant criteria of distinction, since an exchange of poetry was at the same time an intensely competitive game: poets would be assigned a rhyme category, if not a set of rhymes, and be given a limited amount of time (such as within the burning of an incense stick) to complete a poem; slow or dry wit invited embarrassment, as fellow poets were ruthless judges who delivered their verdicts in heart, if not in words.

These collaborators, in turn, connected their social circle to a broader sphere of intellectuals choosing to live under the occupation, who might resist joi-

54 Fu, Passivity, Resistance, and Collaboration, xiv.

55 Fu, Passivity, Resistance, and Collaboration, 111. 
ning the RNG but remained sympathetic to the choices that some collaborators had made. Some of these 'accommodators' descended from prominent families, who probably had estates in the occupied area which they were keen to guard. They included Li Xuanti's cousin Li Xuangong, Mao Jingfan's father Mao Guangsheng 冒廣生 (1873-1959, sobriquet Heting 鶴亭) and other descendants of prominent literati families such as Liao Entao (elder brother of the assassinated кмт left-wing leader Liao Zhongkai 廖仲愷 [1877-1925]), Pan Qixuan 潘 其璇 (1898-?, sobriquet Shuji 叔璣, son-in-law of the late Qing reformer Kang Youwei 康有為 [1858-1927]), Zhang Jiangcai 張江裁 (1908-1968, sobriquet Cixi 次溪, student of Kang Youwei), Yuan Rongfa 袁榮法 (1907-1976, sobriquet Shuainan 帥南, grandson of the late Qing viceroy Yuan Shuxun 袁樹勛 [18471915]), Lin Baoheng 林葆恆 (1872-?, sobriquet Renan 訒禽, grand-nephew of Lin Zexu 林則徐 [1785-1850], late Qing reformer and hero of the First Opium War) and Lin Fuzhen 林栈楨 (1873-?, sobriquet 霜杰, great-grandson of Lin Zexu). There were also professional artists, including painters Yang Wuyang, Tao Yun 陶暉 (1898-1964, sobriquet Yunlou 芸樓), and Duan Shi 段栻 (19141969, sobriquet Wuran 無染), calligraphers Shi Xuehong 石學鴻 (1921-2009, sobriquet Yunsun 雲孫) and Xia Yun 蔡允 (?-?, sobriquet Xiachang 遐長), and seal-engraver Gou Zeyu 郭則豫 (189o-1952, sobriquet Fenggu 楓谷). The last group of guests boasted a consortium of cultural distinctions: Zhou Da 周達 (1879-1949, sobriquet Meiquan 梅泉), a stamp-collector, Shi Linhan 石凌漢 (1871-1947, sobriquet Taosu 㢷素), a Chinese-medicine doctor, and Cao Xiyu 曹熙宇 (1904-1975, sobriquet Jingtao 靖陶), a scholar of traditional Chinese theatre. Since their network was based on common interests and expertise in classical-style Chinese poetry, their gatherings thus assumed a certain apolitical outlook. Even the scholar and novelist Qian Zhongshu 錢鐘書 (19101998), then living in Shanghai, maintained his friendship with Mao Xiaolu and Li Xuangong, despite his professed distaste for collaboration. Some of these accommodators never followed the exodus to the hinterland; some returned to the occupied territories for a variety of reasons, which could be as mundane as missing one's house or library. As Pedith Chan's article in this special issue also shows, many of these people, especially professional artists, never suffered post-war consequences for their accommodation with the RNG, even though their livelihood during the Japanese occupation was probably improved because of their social connections with senior collaborators.

Their social interactions were sometimes facilitated, if not necessitated, by the banal fact that they lived in the same physical space and shared the same quotidian experiences. Traditional holidays like Chinese New Year, the Mid-Autumn Festival or the Double Ninth Day were conventionally celebrated among friends, with food, alcohol and poetry. They also gathered to enjoy sea- 
sonal flowers such as osmanthus and plum blossom, and to complain about the extreme summer heat in Nanjing. Li Xuanti, a man known for his generosity, did not spare rare food items such as coffee, eel or 'drunken crabs' to treat his guests. ${ }^{56}$ This undoubtedly added to the popularity of his salons.

'Apolitical' as these poetic exchanges might appear to be, they helped to normalise the occupation, creating a sense of the continuity of Chinese national culture, despite or perhaps precisely because of it. The presence of Japanese sinologists in these exchanges, who sincerely shared their joy in classical Chinese poetry, was the most eloquent argument in supporting the Japanese wartime propaganda that China and Japan enjoyed a shared race and shared culture' (tongzhong tongwen 同種同文), and should thus be natural allies in a Greater East Asia Co-Prosperity Sphere. The occupation paradoxically became a chance for the revival of traditional Chinese arts (poetry, painting and calligraphy included), marking a sharp contrast with the situation in Chongqing, where the modernist 'New Culture' had marginalised native Chinese cultural traditions, ${ }^{57}$ and in Yan' an, where Mao Zedong's red star was rising and a Rectification Movement was brewing to convince and compel intellectuals to 'learn the language of the people'. These exchanges thus created the illusion that a truly native and national Chinese culture was blooming under Japanese patronage. Unsurprisingly, therefore, the regime funded Li Xuanti's weekly salons.

The composition of Li's social circle also shows the murky boundary between collaboration and accommodation. After the war, Li's cousin Xuangong, like a number of other poets named in this paper, was broadly commended for refusing to serve the collaborationist state. But they found no difficulty in joining Xuanti's parties and wrote poems in sympathetic exchanges. Arguably, it was already a kind of 'sin' to survive under the occupation, instead of sacrificing one's life in resistance-more so if one sought to live an acceptably good life, thus accepting benefit from various actors whose political or economic power was ultimately dependent on the patronage or tolerance of the occupying force. To live was to negotiate with reality. The line separating collaboration from accommodation was drawn in sand. Between the most avid 'collaborationist' who fully subscribed to the occupier's agenda and the most unflinching resister, there was a broad grey zone of politics, morality and action which refuses a clear definition.

56 See Mao Xiaolu and Li Peiqiu, 'Qiaoxi caotang change shi' 橋西草堂唱和詩 (Exchange poems in the West Bridge Thatched Cottage), Tongsheng 2, 10 (1942): 106; Duan Shi, 'Qiaoxi caotang change shi', Tongsheng 2, 12 (1943): 103. 
The celebration of Lu You's birthday in 1943 appears to have been the last major social gathering at the Thatched Cottage. Towards the end of the year, Wang Jingwei's health rapidly deteriorated. By the end of January 1944, he was bedridden, besieged by high fever and incontinence. On 3 March, Wang was flown from Nanjing to Nagoya and would never set foot on Chinese soil again. The end was near. The ranking collaborators knew that Wang was their best hope for a post-war political deal; without him, the future was gloomy. It was unclear whether Li continued to receive state funding for his literary salons during Wang's illness or after his death. Very few of his poems from 1944 have survived.

Wang Jingwei passed away in Nagoya in the afternoon of 10 November 1944. Li probably resigned and left for Shanghai soon after the funeral. Like most poets in his social circle lucky enough to survive the post-war purge, Li Xuanti in his remaining days would not talk about his collaboration again. Regardless of whether there was any justification for joining the Wang regime, the decision to do so was not worth defending. Amnesia and aphasia, it appears, were common diseases assailing the survivors of the RNG who remained in mainland China. After the foundation of the PRC, and despite his poverty, Li Xuanti continued to lead the life of a 'debonair scholar', spending his days in 'elegant gatherings' and Peking opera theatres, probably at the cost of his friends. The social circle of traditionally educated elites provided a safe space for him to construct a stable cultural identity, which continued to transcend the politics and ideologies of the day. Again, cultural practices normalised life under otherwise abnormal circumstances. But those years were the last rays of sun before the red terror in the name of 'continuous revolution', starting in 1957, would rip open the social fabric of this life, leading eventually to the catastrophic Cultural Revolution. The Peking opera plays that Li wrote would be denounced as 'poisonous weeds' (ducao 毒草), to be replaced by 'Revolutionary operas' (yangbanxi 樣板戲). Mei Lanfang's student Yan Huizhu 言慧珠 (1919-1966), whom Li also befriended and praised as a new 'Goddess of the Luo River',58 would commit suicide to defend her dignity. Li Xuanti's death in 1961 was thus rather opportune. He managed to hide 'in a lotus root's hole' from the cosmic flood after all.

58 Li Xuanti, ‘Guan jiuzuo Luoshen ju zeng Huizhu’ 觀舊作洛神劇贈慧珠 (To Huizhu, after watching the 'Goddess of the Luo River', my old play), in Sutang shishi, 46. 


\section{Acknowledgments}

An earlier version of this paper was first presented at the workshop 'Cultural and Intellectual Histories of Japanese-occupied China', held at Asia House (London) on 16 September 2019. This workshop was organised through the сотсA Project, and was thus supported by the European Research Council (ERC) under the European Union's Horizon 2020 research and innovation programme (Grant no. 682081).

\section{References}

Assmann, Aleida. 'Canon and archive'. In Cultural Memory Studies: An International and Interdisciplinary Handbook. Edited by Astrid Erll and Ansgar Nünning (Berlin: De Gruyter, 2008).

Assmann, Jan. Cultural Memory and Early Civilization:Writing, Remembrance, and Political Imagination (Cambridge: Cambridge University Press, 2011).

Barrett, David, and Larry N. Shyu (eds). Chinese Collaboration with Japan, 1932-1945 (Stanford, CA: Stanford University Press, 200o).

Berkowitz, Alan. Patterns of Disengagement: The Practice and Portrayal of Reclusion in Early Medieval China (Stanford, CA: Stanford University Press, 200o).

Boyle, John Hunter. China and Japan at War 1937-1945: The Politics of Collaboration (Stanford, CA: Stanford University Press, 1972).

Brook, Timothy. 'Collaborationist nationalism in occupied wartime China'. In Nation Work: Asian Elites and National Identities. Edited by Timothy Brook and Andre Schmid (Ann Arbor: University of Michigan Press, 200o).

Brook, Timothy. Collaboration:Japanese Agents and Local Elites in Wartime China (Cambridge MA: Harvard University Press, 2005).

Brook, Timothy. 'Hesitating before the judgment of history'. Journal of Asian Studies 71, 1 (2012): 103-114.

Du Fu 杜甫. Du shixiang zhu 杜詩詳注. Edited by Qiu Zhao' ao 仇兆鰲 (Beijing: Honghua shuju, 1979).

Du Fu. Poetry of Du Fu. Translated by Stephen Owen (Berlin: De Gruyter, 2016).

Duan Shi 段栻. ‘Qiaoxi caotang change shi', Tongsheng 同聲 (Accord) 2, 12 (1943): 103.

FitzGerald, Carolyn. Fragmenting Modernisms: Chinese Wartime Literature, Art, and Film, 1937-1949 (Leiden: Brill, 2013).

Fu, Poshek. Passivity, Resistance, and Collaboration: Intellectual Choices in Occupied Shanghai, 1937-1945 (Stanford, CA: Stanford University Press, 1993).

Huang Xiao 黃驍. 'Bie pu xinsheng pei Meilang: Mei Lanfang yu Zhuiyuxuan "muliaozhang” Li Shikan’ 別譜新聲配梅郎：梅蘭芳與緅玉軒”幕僚長'李釋戴 (Writing an- 
other tune for Mei: Mei Lanfang and his 'chief counsellor' Li Xuanti). Zhongguo xiqu xueyuan xuebao 中國戲曲學院學報 (Bulletin of the National Academy of Chinese Theatre Arts) 39, 4 (2018): 38-42.

Li Xuanti 李宣倜. 'Bumei' 不寎 (Sleepless). Guoyi 國藝 (National Arts) 1, 2 (1940): 5 O.

Li Xuanti. 'Jiuyue ershisiri yezuo' 九月二十四日夜作 (Written in the evening of 24 September). Guoyi 國藝 (National Arts) 1, 1 (1940): 38.

Li Xuanti. 'Manjiang hong: He Shuangzhaolou yun' 滿江紅·和雙照樓均 (韻) (Matching the rhyme of 'Double-shining tower' [a.k.a. Wang Jingwei] to 'A river full of red'). Guoyi 國藝 (National Arts) 2, 2 (1940): 6.

Li Xuanti. 'Qianti [Gengchen zhongqiu]: He Shuangzhaolou yun'前題 [庚辰中秋]·和雙 照樓韻 (Matching the rhyme of 'Double-shining tower', the same title [Mid-Autumn Day, 1940]). Guoyi 國藝 (National Arts) 2, 3 (1940): 47 .

Li Xuanti. 'Qiaoxi caotang shi liushou' 橋西草堂詩六首 (Six poems in the West Bridge Thatched Cottage). Tongsheng 同聲 (Accord) 1, 1 (1940): 106-108.

Li Xuanti. 'Shiyue erri Linggu si shi tongyou'十月二日靈谷寺示同遊 (Visiting the Linggu Temple on 2 October; written to show my fellow visitors). Guoyi 國藝 (National Arts) 1, 1 (1940): 38.

Li Xuanti. 'Qiaoxi jimu' 橋西即目 (Random sights to the west of the bridge). Tongsheng 同聲 (Accord) 1, 1 (1940).

Li Xuanti. 'Yiyou weijin zaifu' 意有未盡再賦 (Feeling incomplete, I write a second poem) and 'Linggusi tibi' 靈谷寺題壁 (Written on the wall of the Linggu Temple). Guoyi 國藝 (National Arts) 1, 1 (1940): 38.

Li Xuanti. 'Yu meiren: He Shuangzhaolou' 虞美人·和隻照樓 (Matching the rhyme of 'Double-shining tower' to 'Yu the beauty'). Guoyi 國藝 (National Arts) 2, 2 (1940): 34.

Li Xuanti. 'Xizeng Chen Boye' 戲贈陳伯冶 (A witty poem to Chen Boye). Tongsheng 同 聲 (Accord) 1, 1 (1940): 106-107.

Li Xuanti. 'Zhaiju' 齋居 (In my studio). Tongsheng 同聲 (Accord) 1, 1 (1940): 108.

Li Xuanti. 'Ciyun Zihuo' 次均子篗 (Matching the rhyme of Zihuo's poem). Tongsheng 同聲 (Accord) 1, 2 (1941): 110.

Li Xuanti. 'Haishang you chuan yu bing qie si zhe' 海上有傳余病且死者 (On a rumour in Shanghai that I am sick or perhaps even dead). Tongsheng 同聲 (Accord) 1, 6 (1941): 131.

Li Xuanti. 'Zhengyue shiliuri yuhou jian Yuanxi huiyin zhugong' 正月十六日雨後簡元 夕會飲諸公 (After the rain of the sixteen day of the first month, written to invite my friends for a drink). Tongsheng 同聲 (Accord) 1, 4 (1941): 101.

Li Xuanti. 'Dongpo shengri shangke caotang Yizhangshi xiancheng ciyun' 東坡生日 觞客草堂異丈詩先成次韻 (On Dongpo's birthday I invite guests to the Thatched Cottage for a drink; Zhongyi first completed his poem; I thus match its rhyme). Tongsheng 同聲 (Accord) 2, 3 (1942): 112.

Li Xuanti. 'Dongpo shengri yinke caotang de yezi' 東坡生日飲客草堂得也字(On Dong- 
po's birthday I invite guests to the Thatched Cottage for a drink; drawing the lot of 'ye' as the rhyme of my poem). Yayan 雅言 (Elegantiae) 5, 6 (1943): 1.

Li Xuanti. 'Shiyue shiqiri ji Qiaoxi caotang zuo Fangweng shengri’ 十月十七日集橋西 草堂作放翁生日 (Gathering in the West Bridge Thatched Cottage to celebrate Fangweng's birthday on 17 October). Tongsheng 同聲 (Accord) 3, 8 (1943): 49 .

Li Xuanti. Sutang shishi 蘇堂詩拾 (Selected Poems of Sutang) (self-published, 1956; Nanjing Municipal Library Collection).

Liang Hongzhi. 梁鴻志 Yuanjuge shizhu 爱居閣詩註 (The Commentated Edition of Poetry in the Pavilion of Temporal Lodge), Chen Shirong 陳世鎔 commentator. (selfpublished, 1945 [?], Shanghai Municipal Library Collection).

Lin Baoheng 林葆恆. 'Hangongchun: Fangweng shengri’ 漢宮春·放翁生日 (Fangweng’s birthday, to 'Spring in the palace of Han'). Tongsheng 同聲 (Accord) 1, 5 (1941): 148149.

Liu Jie. 'Wang Jingwei and the "Nanjing Nationalist Government"', trans. Konrad Lawson. In Toward a History beyond Borders. Edited by Daqing Yang, Jie Liu, Hiroshi Mitani and Andrew Gordon (Cambridge, MA: Harvard University Asia Center, 2012), $205^{-239 .}$

Liu Wei-Chih 劉威志. Liang Wang heping yundong xia de fushiyanzhi 梁汪和平運動下 的賦詩言志 (Peace Movement: A Discussion on the Classic Poetry of Liang-Wang et al [sic]) (PhD Dissertation, National Tsinghua University, 2017).

Lu You 陸遊. Jiannan shigao jiaozhu 劍南詩稿校註 (A Commentated Edition of the Poetry of Jiannan). Edited by Qian Zhonglian (Shanghai: Shanghai guji chubanshe, 1985).

Ma Guohua 馬國華. ‘Cong Li Xuanti “wolanyi caiqu” changhe kan Minguo xiqu de shanbian’ 從李宣倜握蘭箖裁曲唱和看民國戲曲的嬗變 (On the transformation of traditional theatres in Republican China from Li Xuanti's poetry creations in Orchid Hut). Shaoguan xueyuan xuebao (shehui kexue) 韶關學院學報 (社會科學) (Bulletin of Shaoguan University: Social Sciences) 38, 10 (2017): 34-39.

Mao Xiaolu 冒效魯 and Li Peiqiu 李霖湫. 'Qiaoxi caotang change shi' 橋西草堂唱和詩 (Exchange poems in the West Bridge Thatched Cottage). Tongsheng 同聲 (Accord) 2, 10 (1942): 106.

Ouyang Xun 歐陽詢. Yiwen leiju 藝文類聚 (Classified Extracts from Literature) (Shanghai: Shanghai guji chubanshe, 1982).

Pan Yimin 潘益民 and Pan Rui 潘蒙萑. Chen Fangke nianpu 陳方恪年譜 (Yearly Chronology of Chen Fangke) (Nanchang: Jiangxi renmin chubanshe, 2007).

Qian Zhonglian 錢仲聯. 'Qiaoxi caotang tuyong xu' 橋西草堂圖詠序 (Preface to the collected poems on the painting of West Bridge Thatched Cottage). Tongsheng 同聲 (Accord) 3, 3 (1943): 10.

Ren Yuandao 任援道. 'Mulan huaman' 木蘭花慢 (To 'Magnolia flowers, a slow tune'). Guoyi 國藝 (National Arts) 3, 1 (1941): 33 . 
Rings, Werner. Leben mit dem Feind: Anpassung und Widerstand in Hitlers Europa, 19391945 (Living with the Enemy: Adaptation and Resistance in Hitler's Europe, 19391945) (Munich: Kindler, 1979).

Serfass, David. Le gouvernement collaborateur de Wang Jingwei: Aspects de l'État d'occupation durant la guerre sino-japonaise, 1940-1945 (PhD Dissertation, École des Hautes Études en Sciences Sociales, 2017).

Sima Qian 司馬遷. Shiji 史記 (Records of the Grand Historian) (Beijing: Zhonghua shuju, 1959).

Su Shi 蘇軾. Su Shi shiji 蘇軾詩集 (The Complete Poetry of Su Shi). Edited by Kong Fanli 孔凡禮 (Beijing: Zhonghua shuju, 1982).

Tao Qian 陶潛. Tao Yuanming ji 陶淵明集 (The Poetry of Tao Yuanming), Lu Qinli 逯欽 立 commentator (Beijing: Zhonghua shuju, 1979).

Taylor, Jeremy E. Iconographies of Occupation: Visual Cultures in Wang Jingwei's China, 1939-1945 (Honolulu: University of Hawai'i Press, forthcoming).

Watson, Burton. The Columbia Book of Chinese Poetry (New York: Columbia University Press, 1984).

Xia Jingguan 夏敬觀. 'Shuidiao getou: Fangweng shengri zuo' 水調歌頭·放翁生日作 (On Fangweng's [a.k.a. Lu You] birthday, to 'A water tune'). Tongsheng 同聲 (Accord) 1, 4 (1941): 108.

Yang Mengya 楊萌芽, Qingmo Minchu Songshi pai wenren qunti yanjiu 清末民初宋诗 派文人群体研究 (A Study of the Song-Poetry School at the End of the Qing and the Beginning of the Republican Era) (PhD Dissertation, Fudan University, 2007).

Yang, Zhiyi. 'Return to an inner utopia: Su Shi's transformation of Tao Qian in his exile poetry'. T'oung Pao 99 (2013): 329-378.

Yang, Zhiyi. 'Site: the impossibility of remembering the past at Nanjing'. Modern Chinese Literature and Culture 32, 1 (2020): 259-262.

Yang, Zhiyi. 'The memory of an assassin and problem of legitimacy in the Wang Jingwei regime (1940-1945)'. Harvard Journal of Asiatic Studies (forthcoming).

Yin Qiling 尹奇岭. Minguo Nanjingjiutishirenyajiyu jieshe yanjiu 民國南京舊體詩人雅 集與結社研究 (A Study of the Elegant Gatherings and Societies of Old-School Poets in Nanjing during the Republican Era) (Beijing: Zhongguo shehui kexue chubanshe, 2011).

Yuan Ke 袁珂. Shanhaijingjiaozhu 山海經校注 (A Commentated Edition of the Classic of Mountains and Seas) (Shanghai: Shanghai guji chubanshe, 1980).

Zeng Jili 曾季貍. Tingzhai shihua 艇齋詩話 (Poetry Talks in the Skiff Studio) (Hong Kong: Guangwen shuju, 1971).

Zhou Fohai 周佛海. Zhou Fohai riji quanbian 周佛海日記全編 (The Full Edited Diaries of Zhou Fohai) (Beijing: Zhongguo wenlian chubanshe, 2003).

Zuo Ren 左仁. ‘Mei Lanfang ganen badiaoqian' 梅蘭芳感恩八吊錢 (Mei Lanfang repaying the debt of 'eight strings of coins'). Lantai neiwai 蘭臺內外 (Chinese Theatre Onand Backstage) 3 (2013): 11. 